\title{
水利工程施工中围堰技术的应用研究
}

宋成再

单县水务局

DOI:10.32629/hwr.v4i4.2876

[摘 要] 水利工程在新时代发展的推动下也在不断进步,水利工程中的围堰技术也因此受到广泛关注。我国目前的水利工程建设情况需要对建 设中涉及到的各项技术进行分析,做好水利工程建设,为人民提供更好的服务。本文研究水利工程施工中围堰技术的应用准则及具体应用,希望 对水利工程施工人员起到借鉴作用,为今后的水利工程施工提供更多的参考。

[关键词] 水利工程; 围堰技术; 应用研究

水利工程建设可以降低洪水等自然灾害造成的损失, 提高清洁能源的 利用, 但是目前来说, 水利工程建设中外界的因素会对施工过程造成很大 影响, 而水利工程的重要组成部分围堰技术, 可以将外界因素造成的影响 降到最低, 进而保证水利工程顺利施工。

\section{1 水利工程围堰技术概述}

围堰技术在水利工程中的应用十分广泛, 但是这是一项复杂、系统的技 术, 施工人员掌握围堰技术应用要点就需要对围堰技术进行全面了解。水利 工程围堰技术可以优化水利工程建设, 使工程建设更加科学合理。水利工 程技术不断更新技术和设备, 对我国水利工程的发展也有推动作用。

水利工程围堰技术主要是利用围堰施工来达到施工效果, 围堰施工完 成后的建筑可以永久保留使用, 若是不需要则在完成导流任务以后进行拆 除。围堰技术也可以保护建筑不受水流的腐蚀, 确保施工过程的稳定及安 全, 为施工的顺利完成提供良好条件 ${ }^{[1]}$ 。

\section{2 水利工程中围堰技术应用准则}

2. 1 加强围堰技术的应用

水利工程在当前经济和技术快速发展中若想满足社会需求, 在实际施 工过程中需要加强对围堰技术的改造和应用, 在围堰技术应用过程中, 还 要加强技术水平、围堰建设形势等内容的合理应用。除此以外还要加强对 已经成熟技术的改造, 对围堰技术涉及到的技术设备进行升级, 满足不同 水利工程施工中的需求, 保证围堰技术在水利工程施工中的发展。

2. 2 优化水利工程结构设计

围堰技术需要不断优化结构设计, 来适应不同时代水利工程的需求, 使其更加合理。优化水利工程结构时不仅要升级技术设备, 还要优化水利 工程整体布局。在水利工程施工中, 结合先进信息技术对整个工程进行监 督, 实现围堰技术多个方面的升级 ${ }^{[2]}$ 。

\section{3制定完整建设方案}

在水利工程建设实施之前, 应该提前制定施工方案, 确保围堰工程建 设能够顺利完成。在水利工程实施过程中, 最关键的步骤是要充分调查施 工条件, 对现有的施工设备进行合理改造。此外, 还可以根据水利工程具体 情况来制定相关条例, 完善整个工程的建设方案, 进一步提高水利工程建 设的效率。

\section{3 水利工程中围堰技术的具体应用}

3. 1 依据实际情况设置水利围堰

水利工程施工中的围堰技术其中一个重要作用是挡水, 这样才能够确 保水利工程可以如期完成, 同时水利围堰的结构设计要满足实际需求, 这 样才能在水利工程施工中充分发挥其作用。水利工程在具体施工过程中的 实际进展情况是不同的, 所以水利围堰的设置需要视水利工程具体情况而
定, 根据不同的情况进行合理调整。例如在浅水区域施工时, 水深不超过 $1.5 \mathrm{~m}$, 可以建设河床, 但是在具体施工期间河床出现渗水、漏水问题时就要 在水深不超过 $1.6 \mathrm{~m}$ 和水流不超过 $2 \mathrm{~m} / \mathrm{s}$ 的位置打桩 ${ }^{[3]}$ 。

3.2 制定水利工程施工规范

首先, 施工单位需要对水利围堰工程的施工图纸进行详细设计, 在充 分勘查施工现场以后设计图纸并且做好围堰规划, 选择合适的施工方案; 其次, 明确水利围堰施工流程, 落实各个步骤详细的工作, 确保施工过程顺 利完成; 第三, 确定围堰施工方法以及施工过程中用到的建筑材料等, 确保 施工质量和效率。例如在具体施工方案中, 通过交错上升方式来进行水利 工程填筑。

\section{3加固水利围堰}

水利围堰在建成以后为了确保其稳定性, 需要进行夯实处理, 检测水 利围堰周围是否有漏水、渗水等现象。水利围堰在外界因素影响下容易出 现塌方事故, 此时要做好维护处理, 比如利用木桩、砂石等固定坡面, 以免 发生位移, 降低自然条件的影响, 提高水利围堰的稳定性 ${ }^{[4]}$ 。

3. 4 在围堰中填充粘土

在水利工程施工中可以利用填充黏土的方式增加围堰厚度, 提高围堰 的稳固性, 施工人员需要检测围堰的数据, 并对数据进行分析, 选择合适的 粘土材料进行填充。之后按照分层方式施工, 控制填筑的厚度及施工速度, 确保填筑操作符合标准并且填筑厚度也保持一致, 填充作业结束后用挖土 机进行夯实即可。

\section{4 结束语}

通过本文的研究可得出, 围堰技术是水利工程施工中重要组成部分, 决定着水利工程各行质量的好坏。现阶段我国水利工程中的围堰施工还存 在着许多问题, 为了提高水利工程质量, 施工人员应该熟练掌握围堰技术, 不断改进围堰技术配合水利工程的发展, 提升水利工程整体水平。希望本 文的研究对于水利工程的围堰技术提高有借鉴意义,在不断提高围堰技术 的同时, 推动我国水利工程的发展。

\section{[参考文献]}

[1]王滔,貲波.水利工程施工中围堰技术的应用研究[J].建材与装 饰,2019(29):163.

[2]高原,刘付涛.浅谈水利水电施工对于施工导流和围堰技术的运用 [J].科技创新与应用,2017(9):225.

[3]黄文胜.水利水电施工对于施工导流和围堰技术的运用 [J].通讯世 界,2017(10):184-185.

[4]何东航.水利水电施工对于施工导流和围堰技术的运用 [J].低碳世 界,2019,9(10):111-112. 